\title{
200 area weekly report
}

11 Feb 1954

Du Pont de Nemours (E.I.) and Co., Wilmington, DE (United States). Explosives Dept.

Reproduced and Distributed by:

U.S. DEPARTMENT OF ENERGY

Office of Scientific and Technical Information

P.O. Box 62

Oak Ridge, TN 37831 


\section{DISCLAIMER}

This report was prepared as an account of work sponsored by an agency of the United States Government. Neither the United States Government nor any agency thereof, nor any of their employees, make any warranty, express or implied, or assumes any legal liability or responsibility for the accuracy, completeness, or usefulness of any information, apparatus, product, or process disclosed, or represents that its use would not infringe privately owned rights. Reference herein to any specific commercial product, process, or service by trade name, trademark, manufacturer, or otherwise does not necessarily constitute or imply its endorsement, recommendation, or favoring by the United States Government or any agency thereof. The views and opinions of authors expressed herein do not necessarily state or reflect those of the United States Government or any agency thereof. 


\section{DISCLAIMER}

Portions of this document may be illegible in electronic image products. Images are produced from the best available original document. 
v. I. du Font de Nemours \& Co. Explosives Department Wilmington 98, Deleware.

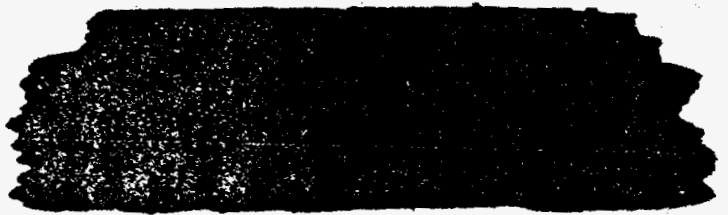

MEMORANDUM

TO: J. B. TINKER (\#1)

FROM: J. P. HOOD PHA
$m+M^{3} / 1$

\#2. J. P. Hood

\#3. V. R. Thayer - R. J. Christl . -

\#4. I. C. Peery - SRP

\#5. I. S. Denser - SRP

\#6. M. H. Wahl - SRL

\#7. W FIIE

Neleted Version DPW-54-4-6-Del.Ver.

$5 R / 4--822$

Fobruary 17, 1954.

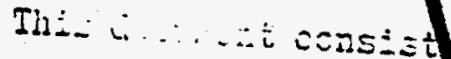

Y.

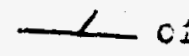

ô

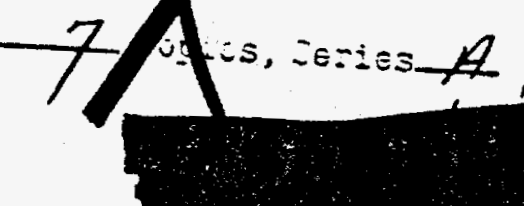

SOLVENT EXTRACTION PLANTS

221-E Building - Gang Valve Corridors Rearrangement Study

Engineering has replied to AED's letter containing comments on the revised gang valve rack mock-up and indicated compliance with most of the requested changes. The exceptions taken appear valid.

Eight preliminary drawings relative to certain phases of this work ffave been submitted by Engineering for approval. The drawings approved with zomment are:

W-161454 - GV corridors - Fire water Deluge Valve Piping - Plans and Sections

N-161480,-1,-2 - GV Corridors - Key Plan Piping Arrangement Sheets 1, 2 and 3

D-113372 - GN Corridors - Separator Strainer - Details

W-161293, $4,-5$ - GV Corridors - Equipment Arrangement - Sheets 1,2 and 3

\section{I7-F Building - Storage Magazine}

The customer storage facilities provided in Building 217-F appear in adequate for the additional requirements of U-235 solution containers. Information is being developed on the design of containers and provisions insure critical safety. When this information is complete, recommendations hili be made regarding increased storage space.

IM Fuel Program - Recovery of U-235

Location of the dissolving and ion exchange facilities for TNX was agreed upon with Technical and Design. The dissolving facilities are to be located where the TNX temporary beater building now stands.

Remote loading of packaged slugs into a g" vertical pipe is to be tried. The test will be run in 717 Building using the mock-up area crane.

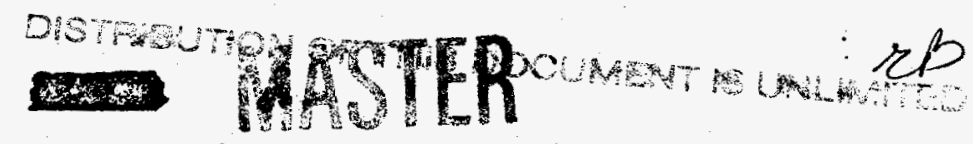


232-F Building

Process Line

Wo hare been advised by the Engineering Department that the assembled components of the Process Line were shipped to SRP from Rochester on February 10, 1954.

\section{2-n Building}

\section{Process Line}

A flow sheet study of methods of increasing thruput of the authorized "F and $\mathrm{H}^{\mathrm{N}}$ process line has been made by AED and Engineering personnel. This work was reviewed with Design Division representatives to acquaint them with present thinking prior to a formal request from AED to start work to determine the feasibility of obtaining additional capacity by following this approach.

Arrnagement drawings of the Process Line components for "H" Line were submitted to the AED by Engineering. These have been reviewed and approved for compliance with Flow Sheet requirements.

Thermal Diffusion Column

Preliminary drawings of a

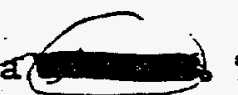
Thermal Diffusion Colum have been reviewed by the AED. Approval was given to permit development of final designs and to start fabrication of the unit. Procurement of auxiliary equipment essential to colurm operation has been started.

233 Building - "nn Line

Crusiner Guider

Designs of a prototype crusher grinder applicable to "D" Iine work were - submitted by the Erigineering Department for comment. The crusher grinder is of the "jaw crusher" type. It is the opinion of" the AED that preliminary improvised tests of grinding a should be made prior to fabrication of the prototype to ascertain the applicability of the jaw type crusher for grinding tisis type of material.

CONSTRUCTION

See attached report.

\section{ITESS FCR MANAGEMENT REVIEW}

None.

JPH/bIt

Attachment with Copies 1 and 2. 


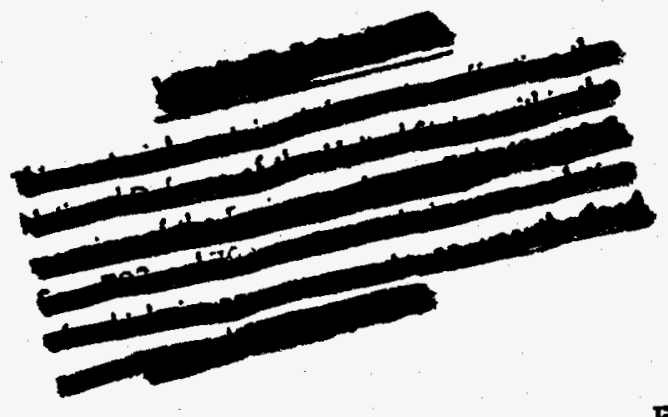
CC:
J. K. Lower
S. D. Salley
J. J. Urban
P. R. Moore
I. C. Peery
J. B. Minker
J. P. Hood (2)
PRD Central File
200 File

Pebruary 5, 1954

TO: J. D. ELIETS

FROM: I. S. DANSER - J. H. HERSHEY

\author{
WEEKLYY REPORT - 200 AREAS \\ PROCESS BUILDINES
}

200-P AREA

\title{
211 Building
}

Check out and run in of equipment in 211 is $85 \%$ complete, At the request of Construction, Operations is preparing a list of items in the waste handling and general purpose evaporator tankage facilities, which still require completion. Approximately 70\% of the itens on the chenical storage punch 2isi, submitted three weeks ago, has been completed.

\section{Building}

Vessel instaliation is complete in the harm canyon except for the dehumidifier, and jumper installation has been sterted on section 18. Thirteen vessels have been set in the hot canyon. The fire, floor flushing and rack flushing sprays were satisfactorily tested in sections 5 through 18 of the hot canyon. The hot canyon crane was satisfactorily run in and the saru canyon crane hoists were load tested. Miscelleneous cleaning and paint retouching is continuing in both canyons.

Hand wheels have been installed on manually operated gang valves and installation is essentially complete. Insulation of gang valve piping is $90 \%$ complete.

Testing and cleaning of piping in the cold feed preparation area are nearly complete. Filters have been instelled in cleaned process 1 ines and screens have been installed ahead of automatic valves. Check out of second level canjon instruments has been started. The Moor on the hot canon side of the cold piping gal.lery in sections 17 and 18 is being Amercoated.

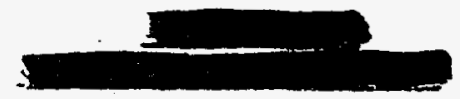


Weokly Report - 200 Areas

Process Buildings

Page 2

Amercoating of floors is complete in sections 5 through 9 , and is in progress in sections 10 through 15 of the cold feed gallery. Pumps and agitators in the cold feed gallery are being checked out. Approximately $50 \%$ of the sample boxes has been reworiced to meet operations requirements for a decontamination surface. Fourth level control rooms are being repainted and panel instruments are being checked out in connection with calibration of third level instruments.

221 "L" Line

The hydrate evaporator cells have been Amorcoated. Stairiless steel hoods and duct work for the rinse and decontamination sinks have been completed. A number of pumps have been taken out for cleaning. The oxide dissolver temperature, level. and specific gravity indicators have been placed on the operating platform handrail.

\section{1 "B" Jine}

Installation of the No. 2 furnace in process room No. 2 is $50 \%$ complete. Insulation of the gang valve steam supply lines is now complete. The recirculating cooling water system is 908 complete. All the metering pumps, the mechanical cabinet exhaust fans and two additional samplers have been checked out and one of the mechanical cabinet exhaust fans has been satisfactorily run in.

\section{Buizding}

Installation of hoods, cabinats, and associated equipment continues in the laboratory wing. Major parts of the decanning machine have been positioned and the stainless steel lining for the south furnace is complete. The process control room and the process room are being partitioned off prior to installation of equipment. Several pieces of equipment have been checked out in the mechanical equipment room and are scheculed for run in next week.

\section{Building}

The heating and yentilating control air compressor is now completels installed. Installation of the inert gas system dryer is $90 \%$ complete. The spare process room is being cleaned and finished in preparation for use as a storage room.

292 Building and Associated Facilities

Loading of the top layer of type "E" gravel is $75 \%$ complote in the sand filter. 117 Building

The second $\mathrm{H}$ Area centrifuge block has been poured and the forms are being erected to pour the $3 \mathrm{rd}$ one for extra minery. Wock up of $F$ Area rack piping is continuing with no set pattern. About $75 \%$ has been cormpleted. 


\section{H AREA}

\section{Building}

The general purpose evaporator and tro hold tanks have been positioned. The rallroad has been completed to the loading platform.

\section{Building}

Work continues on machined beams and support ledges in both canyons. Fifty percent of the imbedded pipe detajis for section 5 warm canyon has been hydrostaticaly tested. The first jigs for section 5 have arrived and are being tried in the cangon. Elghty-itve percent of the ton chamber tubes are in place in both canyons. The stainless steel plating to line the swinming pool wils is all in place. Both walls of the cold feed gallery have been painted to a height of seven feet. Eases are being installed for the third level vessels. One wall in each gang valve corridor has been Amercoated.

\section{Building}

Excavation for this bullding continues and footings are being poured. 292 Building and Associated Facilities

Whterproofing of the outside of the north wall of the sand filter 18 complete and back filling is $90 \%$ complete. Concrete finishing is in progress on the inside of the sand filter. The tent used in $F$ Area for receiving and storing types "fl" and "G" sand has been moved to H Area.

\section{Waste Tank Farm}

The pneumatic test on the cooling colls of tank No. 3 was satiafactorfis completed. Work continues on waterproofing and the brlck wall around the tanks. The 805 Iine has been fabricated to vithin 50 feet of the diversion box. Ine catch tank has been placed in its encasement. 